\title{
The Fourier Transform Infrared (FTIR) Spectroscopic and Mass Spectrometric Metabolomics Studies of Ankaferd Hemostat
}

\author{
Duygu O DEMIRALP ${ }^{1}$, Nasit IGCI' ${ }^{1}$, Yusuf OZTURK ${ }^{2}$, Yavuz BEYAZIT ${ }^{3}$, \\ Ibrahim C. HAZNEDAROGLU ${ }^{4}$ \\ ${ }^{1}$ Ankara University Biotechnology Institute, Proteomics Unit, Ankara \\ ${ }^{2}$ Albio Inc., Department of Research and Development, Istanbul \\ ${ }^{3}$ Turkiye Yuksek Ihtisas Research and Training Hospital,Department of Gastroenterology, Ankara \\ ${ }^{4}$ Hacettepe University Faculty of Medicine, Department of Hematology, Ankara, TURKEY
}

\begin{abstract}
Ankaferd is a traditional folkloric medicine that has been used in Anatolia as a hemostatic agent for centuries. Ankaferd Blood Stopper (ABS) is comprised of a standardized plant extracts of T. vulgaris, G. glabra, V. vinifera, A.officinarum and U. Dioica. ABS modulates cellular apoptotic responses to hemorrhagic stress, as well as the hemostatic hemodynamic activity. Although the effects of ABS mainly depends upon the formation of an encapsulated protein network representing focal points for vital erythrocyte aggregation, integration of the functional proteomics, transcriptomics, and metabolomics will be important for detecting the exact 'mechanism-of-action' of ABS. In order to analyse the fourier transform infrared (FTIR) spectroscopic and mass spectrometric metabolomics, we prepared two-dimensional protein samples and used a Tensor 27 FTIR spectrometer, equipped with a high throughput extension (HTS-XT) accessory. The derivative spectra of metabolomic content of ABS and mass spectrometric and FTIR results were demonstrated. Biological fatty acids such as octanoic acid, heptanoic acid, decanoic acid, eicosanoic acid, octadecanoic acid, hexadecanoic acid, and others have been detected in the metabolomics of ABS. Our results about mass spectrometry and FTIR spectroscopy analyses ABS content within the many crossroads of hemostasis, infection, and neoplasia. Metabolomics studies may shed further light and represent a novel starting point on that perspective for the new avenues of ABS.
\end{abstract}

Keywords: Ankaferd, Mass spectrometry, FITR, Hemostasis

\section{ÖZET}

Ankaferd Hemostat'ın Fourier Transform Infrared (FTIR) Spektroskopik ve Kütle Spektrometrik Metabolomik İncelemesi

Ankaferd, Anadolu'da yüzyllardır hemostatik bir ajan olarak kullanılan geleneksel bir bitkisel ilaçtır. Ankaferd Blood Stopper (ABS), T. vulgaris, G. glabra, V. vinifera, A. officinarum ve U. Dioica adlı bitkilerin standardize karışımdan oluşur. ABS hemorajik strese karşı gelişen hücresel apoptotik cevabı düzenlediği gibi hemostatitik hemodinamik aktiviteyi de düzenler. Her ne kadar ABS'nin temel etki mekanizması eritrosit agregasyonu için gerekli noktalarda enkapsüle protein ağı oluşumunu sağlamak olsa da fonksiyonel proteomiklerin, transkriptomiklerin ve metabolomiklerin yöntem uygulamalarının ABS'nin etki mekanizmasını saptamadaki değeri önemlidir. Bu çalısmada Fourier transform infrared (FIIR) spektroskopik ve kütle spektrometrik metobolomik analizi için 2 boyutlu protein örnekleri hazırladıktan sonra HTS-XT aksesuarı ile donatımış Tensor 27 FTIR cihazı kullanıldı. 
ABS'nin metabolomik içeriği ve kütle spektrometri ve FTIR sonuçları çıkartıldı. Biyolojik yağ asitleri, örneğin; oktanoik asit, heptanoik asit, decanoik asit, eicosanoik asit, octadecanoik asit, hexadecanoik asit ve deriveleri ABS metabolomiks çalışmalarında tespit edildi. Bu çalışmadaki kütle spektrometri ve FTIR spektroskopi analiz sonuçlarının, hemostaz, infeksiyon ve neoplazilerdeki ABS kullanımı ile alakalı yeni başlangıç noktalarına ışık tutacağını düşünmekteyiz.

Anahtar Kelimeler: Ankaferd, Kütle spektrometri, FTIR, Hemostaz

\section{INTRODUCTION}

Ankaferd is an herbal extract which has been used historically as a hemostatic agent in traditional Turkish medicine for centuries. ${ }^{1,2}$ The medicine comprised the standardized mixture of herbs Thymus vulgaris, Glycyrrhiza glabra, Vitis vinifera, Alpinia officinarum and Urtica dioica. ${ }^{3}$ Each one of these herbs is effective over endothelium, blood cells, angiogenesis, cell proliferation, vascular dynamics, and cellular mediators. Glycyrrhiza glabra inhibits angiogenesis, decreases vascular endothelial growth factor production, and cytokine induced neovascularisation. Thymus vulgaris has been shown to exhibit varying levels of antioxidant activity, which may help to prevent in vivo oxidative damage, such as lipid peroxidation associated with atherosclerosis. Vitis vinifera has an anti-atherosclerotic effect. Alpinia officinarum inhibits nitric oxide production in lipopolysaccharide-activated mouse peritoneal macrophages. Urtica dioica produces hypotensive responses through a vasorelaxation effect mediated by the release of endothelial nitric oxide and the opening of potassium channels, and through a negative inotropic action. ${ }^{13,4}$ The basic mechanism of action for ABS is the formation of an encapsulated protein network representing focal points for vital erythrocyte aggregation. ${ }^{5.6} \mathrm{ABS}$ could be used effectively to manage external bleeding in clinical settings such as skin bleeding and/or superficial mucosal blood oozing.?

Ankaferd blood stopper (ABS), a topical hemostatic agent, is approved for the controlling of topical bleedings in Turkey. ${ }^{7-10}$ ABS-induced formation of the protein network with vital erythroid aggregation covers the entire physiological hemostatic process. Mainly, there are distinct important components of the ABS-induced hemostatic network. Vital erythroid aggregation takes place with the spectrin and ankrin receptors on the surface of red blood cells. Those proteins and the required adenosine triphosphate (ATP) bioenergy are included in the
ABS protein library. 5.6 Ankaferd also upregulates GATA/FOG transcription system affecting erythroid functions. Urotensin II is also an essential component of Ankaferd and represents the link between injured vascular endothelium, adhesive proteins, and active erythroid cells. ${ }^{5,6,11,12}$

We have previously reported matrix-assisted laser desorption ionization-time of flight (MALDI-TOF) proteomic molecular analyses, cytometric arrays, transciption analysis, and scanning electron microscope (SEM) ultrastructural examinations of ABS..$^{1.5,5,11-13}$ Since ABS is a relatively novel hemostatic agent, the experience regarding its application in distinct hemorrhagic states is currently expanding. ${ }^{1-3.8-14}$ ABS is currently topically used in bleedings spontaneous or secondary to body hurts, traumas, minor or major surgical interventions. ${ }^{7,15,16}$ It affects not only hemostasis but also wound healing with some antibacterial properties..$^{17-19}$ The great challenge regarding the 'mechanism-of-action' of Ankaferd is to integrate proteomics, transcriptomics, and metabolomics information to give a more complete biological picture of the hemostatic agent. However, little is known about the interrelationships between proteomic content of ABS and its metabolomics, i.e; the study of chemical processes involving metabolites. Several hypotheses were raised the proteomics, transcriptomics, and metabolomics of ABS. In the present study, Fourier Transform Infrared spectroscopy (FTIR) was used to rapidly screen the content of ABS. FTIR is a technique which is used to obtain an infrared spectrum of absorption, emission, photoconductivity or Raman scattering of a given product. ${ }^{20,21}$ The multiplex and throughput advantages of FTIR have opened up new areas of application including detecting the metabolite content of a liquid medicine as like $\mathrm{ABS} .^{20}$ Integration of functional proteomics, transcriptomics, and metabolomics will be important for detecting the exact 'mechanism-of-action' of the pleiotropic medicine Ankaferd since the clinical 
conditions of ABS use are increased as hemorrhagic problems persist despite available anti-hemorrhagic interventions. ${ }^{1,8-10}$

\section{MATERIALS AND METHODS}

\section{Two-dimensional (2D) sample preparation}

The protein samples for 2D gel electrophoresis were prepared as follows: $20 \mathrm{ml}$ of Ankaferd solution was precipitated with Trichloroacetic Acid Precipitation (TCA). $100 \mu \mathrm{l}$ of $100 \%$ TCA. was added for each $1 \mathrm{ml}$ of sample after the vortex and ice bath incubation for $15 \mathrm{~min}$ spined at $14,000 \mathrm{~g}$ for $10 \mathrm{~min}$ at room temperature. The pellet was washed with 1 $\mathrm{ml}$ of ice-cold $85 \%$ acetone, vortex to disperse pellet, then spin at top speed for $5 \mathrm{~min}$ at room temp. Dry the pellet in a Speed Vac for 10-20 min to remove residual solvent. Pellet was re-suspended in $300 \mu \mathrm{l}$ of $2 \mathrm{D}$ sample rehydration solution containing of; $7 \mathrm{M}$ Urea (Sigma, USA), 2M ThioUrea (Sigma, USA), \%0.2 pH 3-10 linear IPG Ampholyte (Bio-Rad Laboratories, USA)., $\% 4$ CHAPS(Sigma, USA), \%1 HED (2-hydroxyethyldisulfide, Sigma, USA), \%1 DTT (Dithiothreitol Sigma, USA). The total protein concentration was measured using the BCA protein assay Kit (Pierce, Rockford, USA).

\section{Fourier Transform Infrared Spectroscopy (FTIR) Analyses}

A Tensor 27 FTIR spectrometer, equipped with a high throughput extension (HTS-XT) accessory, was used. The microplate was mounted in the FTIR-HTS-XT to enable acquisition of infrared spectra. The system was purged with dry nitrogen to reduce water vapour and $\mathrm{CO}_{2}$. All samples were analysed simultaneously. The infrared spectra were collected from 400 to $4000 \mathrm{~cm}^{-1}$ using a Deuterated triglycine sulphate detector. Each acquisition consisted of 512 interferogram scans with a spectral resolution of $4 \mathrm{~cm}^{-1}$. A Blackman-Harris three-term apodisation and a zero-filling factor of two were applied. The data were analysed using Optics User Software. Second derivative and vector normalisation were applied to all spectra to resolve and enhance the intensity of the weak bands. The second derivative of the original spectra was used to identify the peak frequencies of characteristic compo- nents. Since the band intensity or integrated area derived from the second derivative spectra is directly proportional to the concentration, the integrated areas of C-H stretching bands were calculated from the second derivative spectra for preliminary investigation of the ABS content. Assignments for the major bands observed in FTIR spectra of ABS are determined. Mass spectrometry analyses revealed comparable results with the FTIR spectra results.

\section{RESULTS}

The assignments for the major bands observed in FTIR spectra of ABS are determined in this study. Based on those analyses, biological fatty acids such as octanoic acid, heptanoic acid, decanoic acid, eicosanoic acid, octadecanoic acid, hexadecanoic acid, and others have been detected in the metabolomics of ABS (Tables 1 and 2). The metabolic content of ABS that had been evaluated via the FTIR spectroscopy and mass spectrometry analyses revealed comparable results. The content of the ABS corresponding to mass spectrometry and FITR are depicted in Tables 1 and 2.

\section{DISCUSSION}

In this study, metabolic content of ABS has been evaluated via FTIR spectroscopy and mass spectrometry analyses. MALDI-TOF. A wide variety of biological fatty acids were found such as octanoic acid, heptanoic acid, decanoic acid, eicosanoic acid, octadecanoic acid, hexadecanoic acid, and others as depicted in the Tables. The effects of ABS on hemostasis and thrombosis have been demonstrated in preclinical and clinical grounds. $.^{1,8-10,22-28} \mathrm{Ex}-$ perimental studies have set the preclinical stage for the development of this hemostatic product . Acute mucosal toxicity, hematotoxicity, hepatotoxicity, nephrotoxicity, and biochemical toxicity were not observed during the short-term follow-up of the animals. ${ }^{29}$ Those preclinical results reflect a starting point to search any possible systemic confounding effect of ABS when applied to internal topical surfaces. The usage of ABS as a hemostatic agent in external hemorrhages and in dental treatment in humans constitutes the first hints on ABS's safety and efficacy in humans. ${ }^{13,30}$ A phase I double-blinded, 


\begin{tabular}{|ll|}
\hline $\begin{array}{l}\text { Table 1. The metabolomics content of Ankaferd correspond- } \\
\text { ing to the mass spectrometry and FITR }\end{array}$ \\
\hline $\begin{array}{ll}\text { 1. Cyclohexasiloxane } & 21 \text { Benzeneethanamine } \\
\text { 2. Dodecamethyl } & 22 \text { Isoproterenol tri-tms derivative } \\
\text { 3. Dodecamethylcyclohexasiloxane } & 23 \text { Octanoic acid } \\
\text { 4. Bistrimethylsilyl butethal } & \text { 24. Heptanoic acid } \\
\text { 5. Acetic acid } & \text { 25. Propyl ester Propyl heptanoate } \\
\text { 6. Cyclopentasiloxane } & \text { 26. Alpha.-d-glucpyranoside } \\
\text { 7. Benzeneacetic acid } & \text { 27. Nonanal (cas) } \\
\text { 8. Trimethylsilyl ester } & \text { 28. Heptane } \\
\text { 9. Benzoic acid } & \text { 29. Hexanoic acid } \\
\text { 10. Tetradecanoic acid (cas) } & \text { 30. Hexadecanoic acid (cas) } \\
\text { 11. Benzeneethanamine } & \text { 31. Decanoic acid (cas) } \\
\text { 12. n-((pentafluorophenyl)methylene) } & \text { 32. Eicosanoic acid } \\
\text { 13. Tetradecamethylcycloheptasiloxane } & \text { 33. Octadecanoic acid (cas) } \\
\text { 14. Cycloheptasiloxane } & \text { 34. Palmitic acid } \\
\text { 15. Tetracosamethylcyclododecasiloxane } & \text { 35. Palmitinic acid } \\
\text { 16. Hexadecamethylcyclooctasiloxane } & \text { 36. Bistrimethylsilyl butethal } \\
\text { 17. Hexadeca } & \text { 37. Octademethylcyclononasiloxane } \\
\text { 18. Diethyl phthalate } & \text { 38. Cyclononasiloxane } \\
\text { 19. Dibutyl phthalate } & \text { 39. n-octadecanoic acid } \\
\text { 20. Allyl ethyl ester } & \text { 40. Decylic acid }\end{array}$ \\
\hline
\end{tabular}

\begin{tabular}{|c|c|}
\hline & 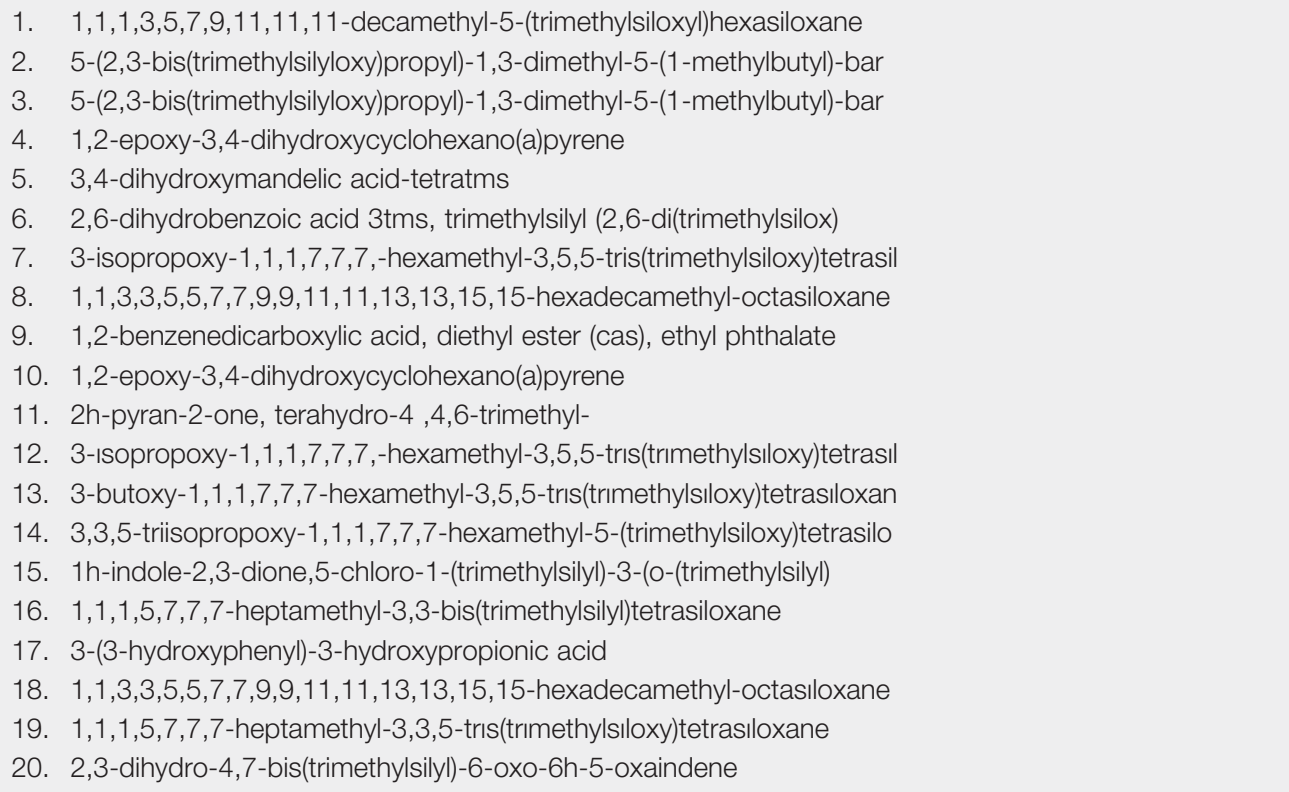 \\
\hline
\end{tabular}

randomized, cross-over, placebo-controlled clinical study with a 5 days' wash-out period between the cross-over periods in healthy volunteers indicated the safety of ABS. ${ }^{10}$ Physiological cell-based coagulation could be clinically managed via topical
ABS application to prevent and treat bleeding in many distinct clinicopathological states. ${ }^{1,8-10,13,16,28}$ There are distinct important molecular components of the Ankaferd-induced hemostatic network. Vital erythroid aggregation takes place with the spectrin, 

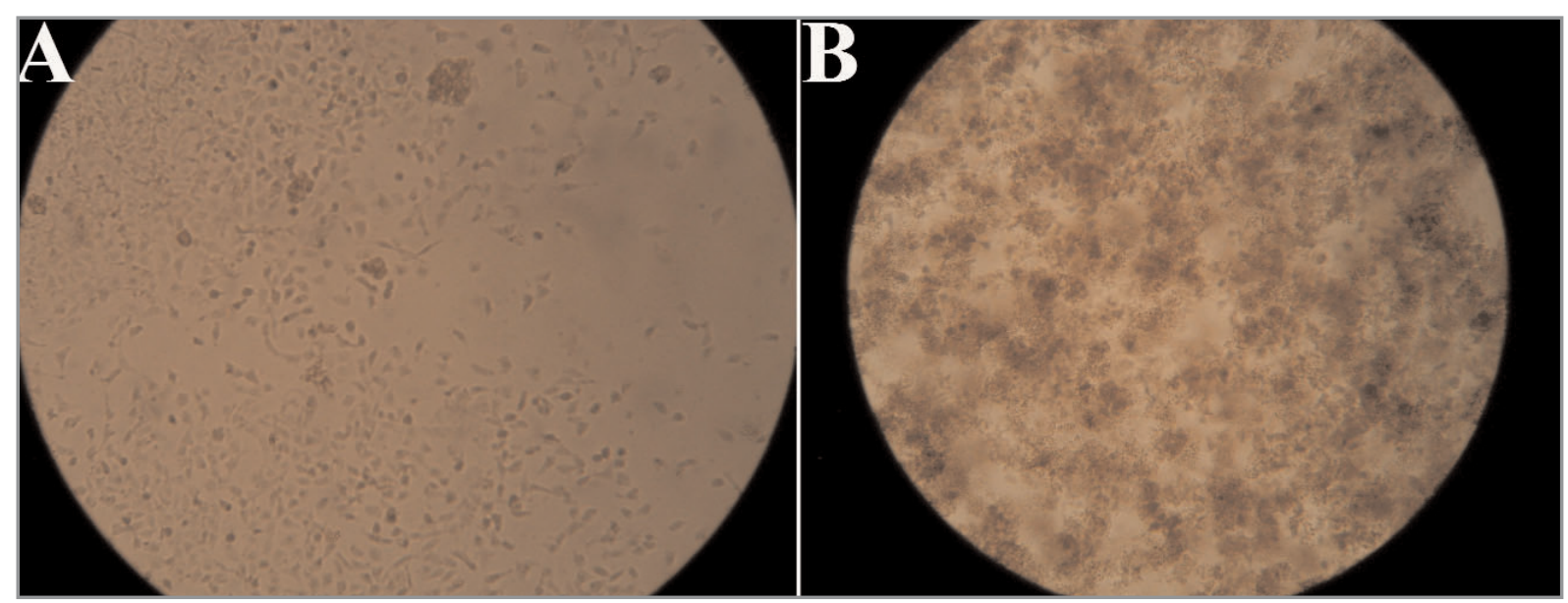

Figure 1. Endothelial cells adhered to each other upon the ABS application to the HUVEC. This cellular adheration is vital, strong and reversible (A and $B$ )

ankryn and actin proteins on the membrane of red blood cells. Essential erythroid proteins (Ankryn recurrent and FYVE bundle containing protein 1, Spectrin alpha, Actin-depolimerisation factor, Actin-depolimerizing factor, LIM bundle and actine binding subunit 1 isoform a, LIM bundle and actine binding subunit 1 isoform $b$, NADP-dependent malic enzyme, NADH dehydrogenase (Ubiquinone) 1 alpha subcomplex, Mitochondrial NADP (+) dependent malic enzyme 3, Ribulose bisphosphate carboxylase large chain, Maturase $\mathrm{K}$ ) and the required ATP bioenergy (ATP synthase, ATP synthase beta subunit, ATP synthase alpha subunit, ATP-binding protein $\mathrm{C} 12$, TP synthase $\mathrm{H}+$ transporter protein, ADF, Alpha-1,2-glycosyltransferase ALG10A) are included in the protein library of Ankaferd. Ankaferd also upregulates GATA/FOG transcription system affecting erythroid functions and urotensin II..$^{11,12}$ Initial vascular dynamic response to ABS is vasoconstriction while the late effect is vasodilatation.31 Since fatty acids are essential to maintain vascular dynamics and hemostatic actions, the results of our present study would help to explain pharmacobiological effects of ABS on hemostasis.

Ankaferd, besides its hemostatic activity, may also inhibit the growth of bacteria. ${ }^{17,18}$ Anti-infectious activity of Ankaferd may represent an advantage over its current clinical use, since it inhibits the growth of bacteria in the area used mainly for its hemostatic activity such as traumatic infected wounds. The antimicrobial activity of Ankaferd was tested against many pathogens. ${ }^{19}$ The isolates included A.baumannii, E.coli, K.pneumonia, P.aeruginosa, Enterobacter spp., Stenotrophomonas maltophilia, Methicillin-resistant Staphylococcus aureus (MRSA), methicillin resistant coagulase negative Staphylococcus, vancomycin susceptible Enterococcus and vancomycin-resistant enterococci (VRE). Antibacterial activities of Ankaferd against several gram positive and gram negative food and human pathogens, were also reported..$^{17-19}$ The mechanism of action regarding the anti-infective actions of ABS is currently unknown. Several proteins (Homo sapiens malic enzyme 1, Dynactin 5, Cofilin, Utrophin, Mucin16 (CD164-sialomucin-like-2 protein), Chalcon flavonon isomerase-1, Chalcon flavonon izomerase 2, Helezonal bundle transporter protein-141, Hypothetical protein LOC283638 isoform 1, Hypothetical protein LOC283638 isoform 2 , Complex 1 intermedia related protein 30 ) in the proteomic analyses represent an important step to elucidate how Ankaferd biologically affects the components of numerous pathogens. Biological fatty acids such as octanoic acid, heptanoic acid, decanoic acid, eicosanoic acid, octadecanoic acid, hexadecanoic acid, and others (Tables 1 and 2) are considered as anti-infectives. ${ }^{32-34}$ Therefore, our results indicating the presence of fatty acids in the metabolic content of Ankaferd could be another clue of the anti-infective actions of the ABS.

ABS also has cellular effects. ABS has numerous effects on the cellular microenvironment. The ef- 
fects of ABS on two important endothelial hemostatic molecules, Endothelial Protein C Receptor (EPCR) and plasminogen activator inhibitor-1 (PAI-1) were previously examined.$^{35} \mathrm{ABS}$ has dual diverse dynamic reversible actions on EPCR and PAI-1 inside vascular endothelial cells in the model of Human Umbilical Vein Endothelial Cells (HUVEC) ${ }^{35}$ Immediate enhanced expression of pro-hemostatic PAI-1 and down-regulated anti-coagulant EPCR upon the exposure of ABS were compatible with the sudden anti-hemorrhagic efficacy of ABS. Figure 1 depicts the effects of ABS on HUVEC cells. Lipopolysaccharides (LPS), large molecules acting as endotoxins and elicit strong immune responses, application to HUVEC caused ABS-induced up-regulations in the expressions of EPCR and PAI-1 indicating that ABS could act as a topical biological response modifier. ${ }^{35}$ EPCR and PAI-1 molecules are considered as the associates of Protease Activator Receptor 1 (PAR-1). ABS caused dosedependent reversible PAR-1 down-regulation in HUVEC cellular model. "LPS challenge" to HUVEC enhanced ABS-induced sustained down-regulations in the expressions of PAR- $1 .^{36} \mathrm{ABS}$ is therefore considered as a topical biological response modifier. ABS has de novo effects on apoptosis. ${ }^{37} \mathrm{Sin}-$ ce fatty acids are essential to maintain cellular life in health and disease, the findings of our present study further indicated that ABS may act as a topical biological response modifier.

The pleiotropic effects of ABS on vascular endothelium, blood cells, angiogenesis, cellular proliferation, vascular dynamics and cellular mediators should be investigated to determine its potential role in many pathological states, including neoplastic disorders, infectious diseases, and inflammation. Our results about the FTIR spectroscopy and mass spectrometry analyses within many crossroads of hemostasis, infection, and neoplasia in this report may shed further light and represent a novel starting point on that perspective for the new avenues of ABS.

\section{REFERENCES}

1. Beyazit $\mathrm{Y}$, Kurt M, Kekilli M, et al. Evaluation of hemostatic effects of ankaferd as an alternative medicine. Altern Med Rev 15: 329-336, 2010.
2. Haznedaroglu BZ, Beyazit $Y$, Walker SL, HaznedarogIu IC. Pleiotropic cellular, hemostatic, and biological actions of Ankaferd hemostat. Crit Rev Oncol Hematol 83: 21-34, 2012.

3. Goker H, Haznedaroglu IC, Ercetin S, et al. Haemostatic actions of the folkloric medicinal plant extract Ankaferd Blood Stopper. J Int Med Res 36: 163-170, 2008.

4. Goker H, Haznedaroglu IC, Ercetin S, et al. Haemostatic actions of the folkloric medicinal plant extract, Ankaferd Blood Stopper. Blood 110: 53b-53b, 2007.

5. Haznedaroglu BZ, Haznedaroglu IC, Walker SL, et al. Ultrastructural and morphological analyses of the in vitro and in vivo hemostatic effects of Ankaferd Blood Stopper. Clin Appl Thromb Hemost 16: 446-453, 2010.

6. Haznedaroglu IC. Molecular Basis of the Pleiotropic Effects of Ankaferd Blood Stopper. IUBMB Life 61: 290, 2009.

7. Al B, Yildirim C, Cavdar M, et al. Effectiveness of Ankaferd blood stopper in the topical control of active bleeding due to cutaneous-subcutaneous incisions. Saudi Med J 30: 1520-1525, 2009.

8. Ak G, Cakir O, Kazancioglu HO, et al. The use of a new hemostatic agent: Ankaferd Blood Stopper in hemophiliacs. Haemophilia 16: 51, 2010.

9. Arslan S, Haznedaroglu IC, Oz B, et al. Endobronchial application of Ankaferd blood stopper to control profuse lung bleeding leading to hypoxemia and hemodynamic instability. Resp Med 27: 631.e1-2, 2009.

10. Balcik OS, Koroglu M, Cipil H, et al. A Placebo-Controlled, Randomized, Double-Blinded, Cross-Over Phase I Clinical Study to Demonstrate Safety of Ankaferd Blood Stopper Topical Usage In Healthy Volunteers. Int J Lab Hem 32(Suppl 1): 126-127, 2010.

11. Demiralp DO, Haznedaroglu IC, Akar N. Functional proteomic analysis of Ankaferd Blood Stopper. Turk J Hematol 27: 70-77, 2010.

12. Yllmaz E, Gulec S, Haznedaroglu IC, Akar N. The effects of Ankaferd $\otimes$ Blood Stopper on transcription factors in HUVEC and erythrocyte protein profile. Turk J Hematol 28: 276-285, 2011.

13. Ercetin S, Haznedaroglu IC, Kurt M, et al. Safety and Efficacy of Ankaferd Blood Stopper in Dental Surgery. UHOD 20: 1-5, 2010.

14. Turhan N, Kurt M, Shorbagi A, et al. Topical Ankaferd Blood Stopper administration to bleeding gastrointestinal carcinomas decreases tumor vascularization. Am J Gastroenterol 104: 2874-2877, 2009.

15. Meric TA, Korkut AY, Kahya V, et al. Prospective, randomized, controlled clinical trial of Ankaferd Blood Stopper in patients with acute anterior epistaxis. Eur Arch Otorhinolaryngol 267: 1377-1381, 2010.

16. Teker AM, Korkut AY, Gedikli O, et al. Prospective, controlled clinical trial of Ankaferd Blood Stopper in children undergoing tonsillectomy. Int J Pediatr Otorhinolaryngol 73: 1742-1745, 2009. 
17. Akkoc N, Akcelik M, Haznedaroglu IC, et al. In Vitro Anti-Bacterial Activities of Ankaferd Medicinal Plant Extract. Turkiye Klinikleri J Med Sci 29: 410-415, 2009.

18. Saribas Z, Sener B, Haznedaroglu IC, et al. Antimicrobial activity of Ankaferd Blood Stopper against nosocomial bacterial pathogens. Cent Eur J Med 5: 198202, 2010.

19. Tasdelen FN, Tanriverdi CY, Coban AY, et al. Antimicrobial activity of plant extract Ankaferd Blood Stopper. Fitoterapia 80: 48-50, 2009.

20. Liu $Y, X u Y$, Zhang $Y$, et al. Detection of cervical metastatic lymph nodes in papillary thyroid carcinoma by Fourier transform infrared spectroscopy. Br J Surg 98: 380-384, 2011.

21. Sirikwanpong S, Dahlan W, Ngamukote S, et al. The Alterations of Erythrocyte Phospholipids in Type 2 Diabetes Observed after Oral High-Fat Meal Loading: The FTIR Spectroscopic and Mass Spectrometric Studies. J Clin Biochem Nutr 47: 111-120, 2010.

22. Aysan E, Bektas H, Ersoz F, et al. Ability of the ankaferd blood stopper(R) to prevent parenchymal bleeding in an experimental hepatic trauma model. Int J Clin Exp Med 3: 186-191, 2010.

23. Bilgili $H$, Kosar A, Kurt M, et al. Hemostatic efficacy of Ankaferd Blood Stopper in a swine bleeding model. Med Princ Pract 18: 165-169, 2009.

24. Cipil HS, Kosar A, Kaya A, et al. In vivo hemostatic effect of the medicinal plant extract Ankaferd Blood Stopper in rats pretreated with warfarin. Clin Appl Thromb Hemost 15: 270-276, 2009.

25. Huri E, Akgul T, Ayyildiz A, et al. Hemostatic role of a folkloric medicinal plant extract in a rat partial nephrectomy model: controlled experimental trial. J Urol 181: 2349-2354, 2009.

26. Kilic O, Gonen M, Acar K, et al. Haemostatic role and histopathological effects of a new haemostatic agent in a rat bladder haemorrhage model: an experimental trial. BJU Int 105: 1722-1725, 2010.

27. Kosar A, Cipil HS, Kaya A, et al. The efficacy of Ankaferd Blood Stopper in antithrombotic drug-induced primary and secondary hemostatic abnormalities of a rat-bleeding model. Blood Coagul Fibrinolysis 20:185190, 2009.

28. Turhan N, Kurt M, Shorbagi A, et al. Topical Ankaferd Blood Stopper administration to bleeding gastrointestinal carcinomas decreases tumor vascularization. Am J Gastroenterol 104: 2874-2877, 2009.

29. Bilgili $H$, Captug O, Kosar A, et al. Oral systemic administration of Ankaferd blood stopper has no shortterm toxicity in an in vivo rabbit experimental model. Clin Appl Thromb Hemost 16: 533-536, 2010.

30. Baykul T, Alanoglu EG, Kocer G. Use of Ankaferd Blood Stopper as a hemostatic agent: a clinical experience. J Contemp Dent Pract 11: E088-94, 2010.

31. Aktas A, Er N, Onur MA. Effects of ankaferd blood stopper on vascular response in rat carotid artery. UHOD 20: 156-162, 2010.
32. Nair MK, Abouelezz H, Hoagland T, et al. Antibacterial effect of monocaprylin on Escherichia coli O157:H7 in apple juice. J Food Prot 68: 1895-9, 2005.

33. Nair MK, Joy J, Vasudevan P, et al. Antibacterial effect of caprylic acid and monocaprylin on major bacterial mastitis pathogens. J Dairy Sci 88: 3488-3495, 2005.

34. Nair MK, Joy J, Venkitanarayanan KS. Inactivation of Enterobacter sakazakii in reconstituted infant formula by monocaprylin. J Food Prot 67: 2815-2819, 2004.

35. Karabiyik A, Yılmaz E, Gulec S, et al. Dual diverse dynamic reversible actions of Ankaferd on EPCR and PAl-1 inside vascular endothelial cells with and without LPS. Turk J Hematol 29: 361-6, 2012.

36. Karabiyik A, Güleç S, Yilmaz E, et al. Reversible protease-activated receptor 1 downregulation mediated by Ankaferd blood stopper inducible with lipopolysaccharides inside the human umbilical vein endothelial cells. Clin Appl Thromb Hemost 17: E1670, 2011.

37. Huri E, Haznedaroglu IC, Akgul T, et al. Biphasic effects of ankaferd blood stopper on renal tubular apoptosis in the rat partial nephrectomy model representing distinct levels of hemorrhage. Saudi Med J 30: 864868, 2010.

\section{Correspondence}

Dr. Yavuz BEYAZIT

Turkiye Yuksek İhtisas Eğitim ve Araştırma Hastanesi Gastroenteroloji Bölümü

06100 Sihhiye

ANKARA / TURKEY

Tel: (+90.312) 3061320

Fax: (+90.312) 3061344

e-mail: yavuzbeyaz@yahoo.com 